\title{
ISLAMIC CORPORATE SOCIAL REPORTING (ICSR): COMPARING THE DESIRABLE, THE DESIRED AND THE ACTUAL
}

\author{
Rusnah Muhamad, Zulfa Abdul Rahman and Tan Ai Lin
}

\begin{abstract}
Various authors have suggested that culture is a powerful environmental factor, and, therefore, it has the potential to influence the development of the accounting system and practices of a country. In addition, it is claimed that culture also affects the perception and use of the accounting information by individuals. Religion is considered to be a significant cultural factor, and, thus, may have an impact on accounting practices. More specifically, Islam, a religion that is considered to be a way of life (ad-din) that transcends geographical, racial and linguistic differences, has the potential to influence the structure, underlying concepts and the mechanisms of accounting in the Islamic world. In Malaysia, there has been some evidence of corporate social reporting (CSR) among organisations in the absence of any regulatory or legal requirements. This study aims to compare the desirable, the desired and the actual in reporting corporate social responsibility from an Islamic perspective. The empirical study is carried out to identify whether there is any gap in CSR between the desirable (as prescribed by shariah), the desired (as perceived by Malay Muslim accountants) and the actual practices (as observed from the current reporting practices of selected Islamic Business Organizations (IBOs)).
\end{abstract}

Keywords: Corporate Social Reporting; Muslim Accountants; Islam; Islamic Business Organizations; Malaysia

JEL Classification: M14, M41, L25, Z12

\section{Introduction}

Religion, being an aspect of culture (Delener, 1994; Sood and Nasu, 1995; Humphreys, 1996) has considerable influence on peoples' values, habits and attitudes (Delener, 1990), and, therefore, may affect an individual's perception and behaviour. In addition, Archambault and Archambault (2003) demonstrate that the financial disclosure of a corporation is influenced by culture, national systems and corporate systems. Thus, religion has the potential to influence corporate financial reporting (Hamid et al., 1993) as well as the information needs of users of corporate reports (Palau, 2001).

Corporate social responsibility is an evolving concept with the scope to be widened to include more elements (Nor and Hashim, 2014), and is now an industry in its own right (Dusuki, 2008). The fundamental idea embedded in

Corresponding author: Zulfa Abdul Rahman is a Manager at the Institute of Accountants (MIA), email: zulfa@mia.org.my. Datin Dr Rusnah Muhamad is an Associate Professor in the Faculty of Business and Accountancy, University of Malaya and Tan Ai Lin from Universiti Tenaga Nasional. 
corporate social responsibility (or corporate responsibility, as coined by Hillenbrand and Money, 2007) is that organisations have an obligation to work for the social betterment (Frederick, 1994). It is contended that there are circumstances under which religion may affect societal values, such as the accounting system and practices (Hofstede, 1988). Therefore, corporate social responsibility practices could be derived from the teachings of the respective religion. According to Williams and Zinkin (2010), within the area of corporate social responsibility, religion has played a significant role in the development of personal values and behaviour, which influences many areas of business. The concept of corporate social responsibility and social justice has been practiced in the Islamic society for nearly 14 centuries (Mohammed, 2013). In Islam, a believer believes that they are accountable to Allah for all their deeds, as well as their decisions and the intention behind those deeds. A Muslim knows that all the resources within their command are a trust whereby they are accountable to Allah if they misuse them. This sense of responsibility motivates a Muslim to be ethical and this belief plays a vital role in the day-to-day activities of a faithful person that keeps them on the straight path of virtue.

Islam has the potential to influence the structure, underlying concepts and the mechanisms of accounting in the Islamic world (Hamid, Craig, and Clarke, 1993). Thus, it is imperative and beneficial to conduct a study in the Malaysian environment since the majority (more than 60\%) of the population are Muslims. The aim of this study is to determine whether there is any difference in CSR among the desirable (as prescribed by shariah), the desired (as perceived by Malay Muslim accountants) and the actual practices (as observed from the current reporting practices of selected Islamic Business Organizations (IBOs)).

The paper is organized as follows. The first section discusses the impact of culture and religion on accounting. The second section describes CSR from the Islamic perspective. The third section discusses the Islamic corporate social reporting (ICSR) model. The remaining sections report on previous studies, the findings and the conclusion of the study.

\subsection{Impact of Culture and Religion on Accounting}

Culture is the total sum of a way of life, including such things as expected behaviour, beliefs, values, language, and living practices shared by the members of a society; it is the pattern of values, traits, or behaviours shared by the people within a region (Herbig and Dunphy, 1998). Various authors have suggested that culture is a powerful environmental factor (Muhamad, 2006; Palau, 2001; Perera, 1989; Gray, 1988; Violet, 1983; Jaggi, 1975), and, therefore, culture has the potential to influence the development of the accounting system and practices of a country. In addition, it is claimed that culture also affects the perception and the use of accounting information by individuals (Palau, 2001).

Accounting is a social system (Archambault and Archambault, 2003). The adoption of different accounting systems is attributable to composite factors including cultural differences (Doupnik and Salter, 1995; Gray, 1988). It is 
posited that religious beliefs greatly influence the cultural fabric of a country (Archambault and Archambault, 2003). Religion has been identified as being one of the elements in the cultural environment (Hunt and Vitell, 1986) that may impact accounting practices (Baydoun and Willett, 1995; Hopwood, 1983; Briston, 1978; Jaggi, 1975) Therefore, since religion affects the way in which people behave (Sadler, 1970), it affects cultural values (Hamid et al., 1993). Specifically, in this study, the focus is on Islam, in that it is considered as ad-din wa al-Duniya or 'both faith and a way of life' (Abdullah, 1999).

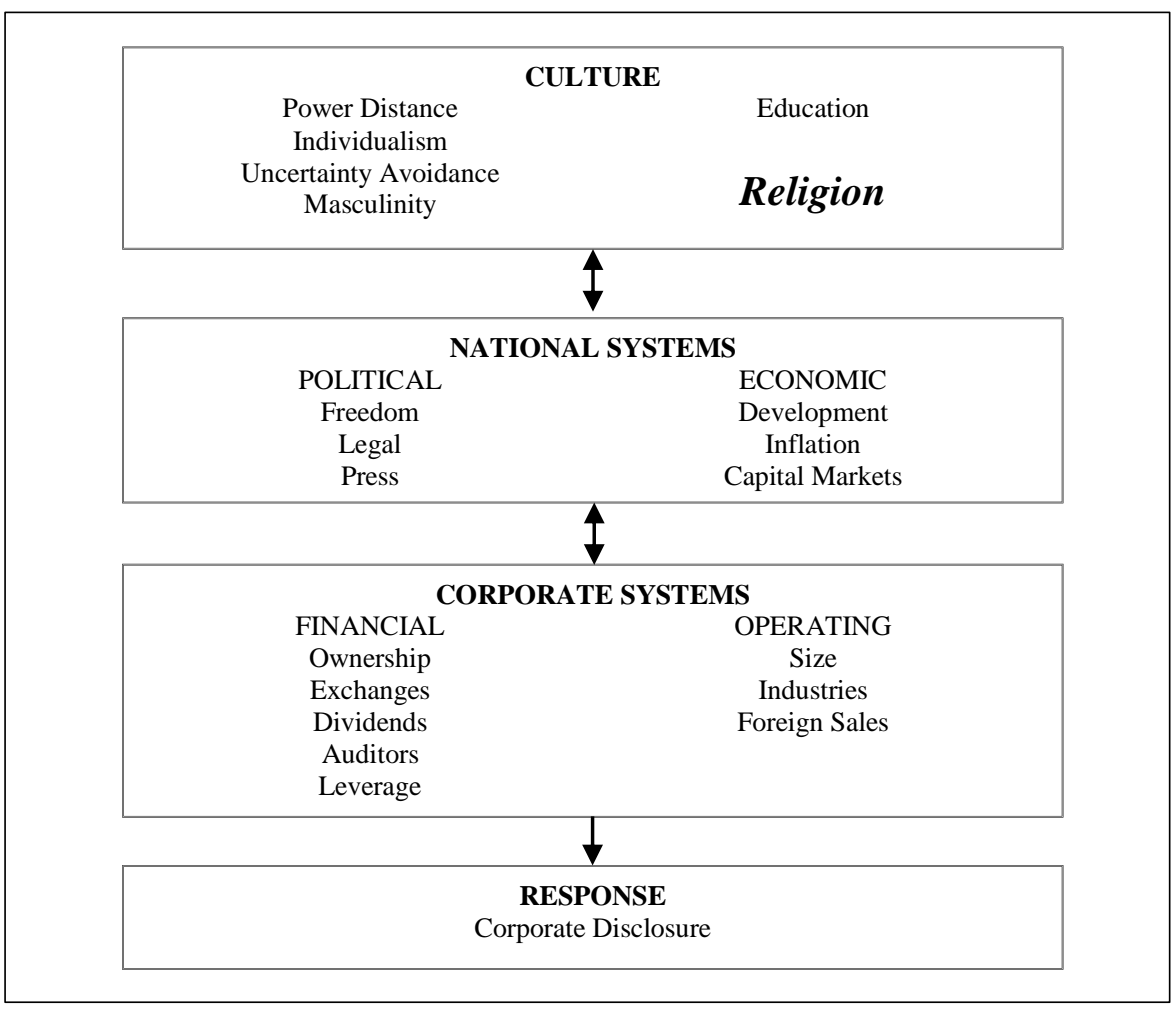

Figure 1: Model of Corporate Disclosure

Source: Archambault and Archambault, 2003

The model of corporate disclosure, as depicted in Figure 1, examines the factors that influence corporate disclosure at the corporate level. The model incorporates culture, which includes religion, with national systems and corporate systems. These factors interact with one another in the model, resulting in a corporation's response regarding the different types of information to be disclosed. However, in this paper, the focus of analysis is limited to the impact of religion in reporting corporate social responsibility information (CSRI) in annual reports. The study also investigates the perceived CSRI to be disclosed by IBOs among Muslim accountants in Malaysia. 


\subsection{CSR from the Islamic perspective}

Islam is not simply a religion that confines its scope to the private life of man (Abdalati, 1998). Indeed, Islam is a complete way of life (ad-din) (Al-Attas, 1985), and its values are universal (shumul) in character, transcending geographical, racial and linguistic differences, and catering for all fields of human existence in all phases of life (Abod, 2002). The belief in the oneness of God (Tawhid) is the key to Islamic faith as described in the Holy Quran. The concept of Tawhid implies that man has to maintain a relationship not only with God (hablun min' Allah), but also with human beings (hablun min'an-nas) and the environment.

The Muslim's relationship with Allah (swt) is one of love and obedience, complete trust and thoughtfulness, peace and appreciation, steadfastness and active service (Abdalati, 1998). Muslims believe that Allah (swt) is always watching the actions of his servants. Therefore, Islamic business organisations (IBOs) are no exception to the obligation to pursue the guidance and law of Islamic mu amalah. IBOs represent companies that fully adopt Islamic principles in their daily operations and the conduct of their business (Muhamad, 2006).

A man's relation with their fellow human beings should be inspired by the values of trust, truthfulness, firmness, fairness, respect of the law, kindness, and tolerance, etc. In business operations, leaders must respect the haq (right) of all parties, such as shareholders, employees, suppliers and the environment. Muslim action towards others must be in a form of amal salih (good deeds), which is the key to the attainment of al-falah (Hassan, 2002).

According to Islam, the protection of the environment, as well as utilization of natural resources for business purposes, should be regarded as a social responsibility. The right to utilize and harness natural resources, which Allah $(s w t)$ has granted man, necessarily involves an obligation on man's part to conserve them both quantitatively and qualitatively (Bakadar, 1997). Shariah Islamiyyah can be classified into three main components; namely, Aqidah, Shariah and Akhlaq (Zaidan, 1999). Shariah consists of two main elements, which are Ibadah and Mu 'amalah. 'Ibadah relates to the practices devoted to Allah (swt), whereas, Mu amalah involves the relationship among human beings for their benefit. Mu amalah generally covers three main elements, which are politic, social and economic (Zaidan, 1999). The concept of full disclosure in the Islamic accounting system, being part of economic activities, is therefore linked with the Shariah Islamiyyah principles through Muamalah. Therefore, the relationship between Tawhid and Shariah Islamiyyah under which the concept of Muamalah stems from, is depicted in Figure 2. 


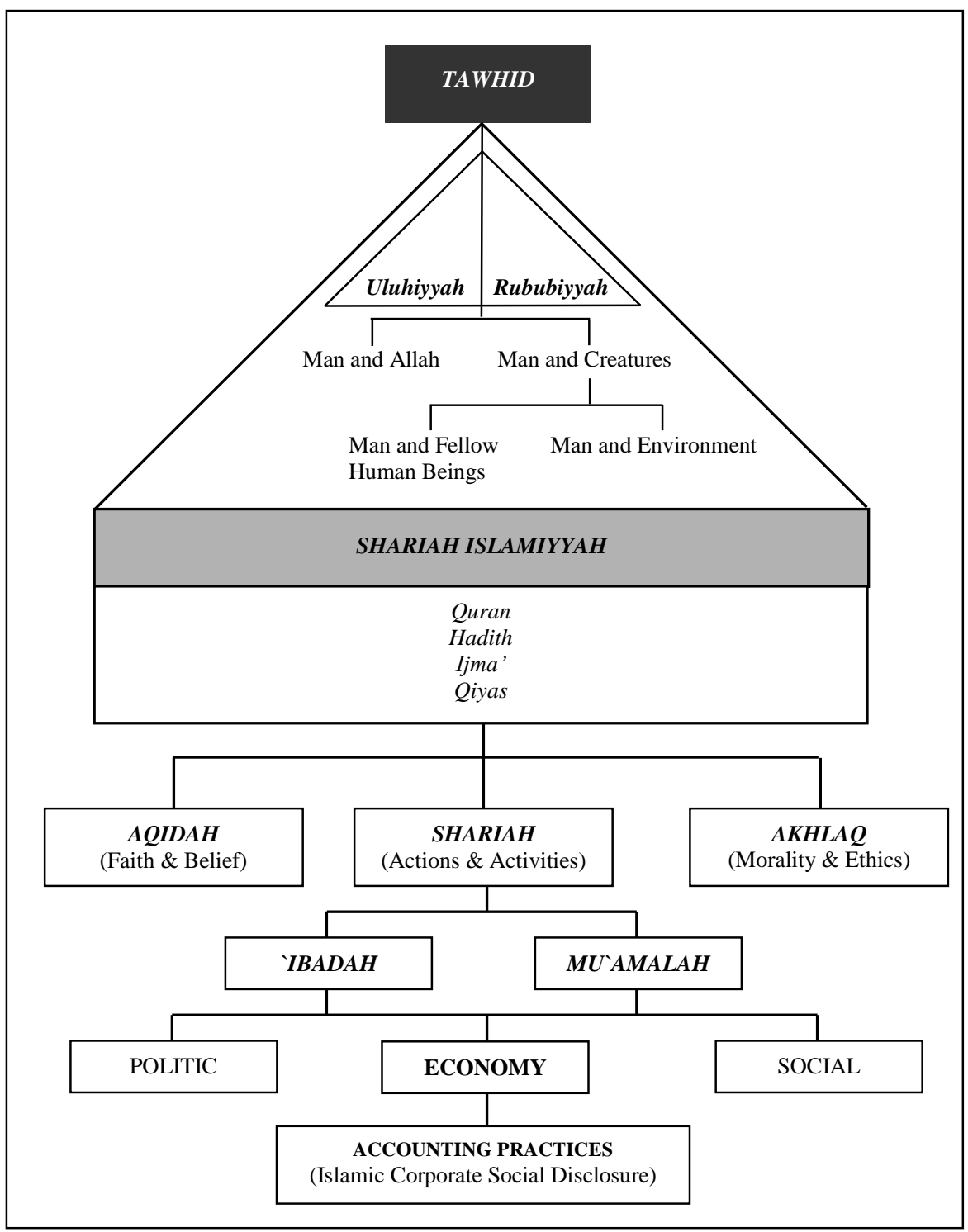

Figure 2: The Framework of Tawhid and Shariah Islamiyyah Source: BIMB, (1994)

In Islam, social responsibility stems from the concept of brotherhood and social justice (Naqvi, 1981). The concept of social justice inspires Muslims not to cause harm to others (Yusoff, 2002), which is strengthened through the concept of ukhuwwah (brotherhood) (Alhabshi, 1994) that makes Muslims responsible to each other. The commitment of Islam to justice and brotherhood demands that Muslims take care of the basic needs of the poor (Naqvi, 1981). 
Based on the axiom of Tawhid, the main objectives of social responsibility should be to demonstrate responsibility not only to Allah $(s w t)$ and society, but also to the environment. As khalifah, mankind is not free but responsible and accountable to Allah (swt) (Haniffa, Hudaib and Mirza, 2004). According to Hassan (2002), mankind has a dual function: (i) as a servant of Allah (swt) and (ii) as khalifah on earth. As a servant of Allah (swt), man needs to worship God, seek God's pleasure, follow God's laws, be good to all the creatures of God and refrain from al-fasad (destruction). On the other hand, as a khalifah on earth, man needs to enforce the Shariah Islamiyyah in his life, maintain the harmony and peace, protect the environment, and fulfil the roles of al-sifah al-mahmudah (good manners), such as, tabligh (advisor), amanah (trust), siddiq (truthfulness) and fatanah (wise).

As khalifah, leaders in IBOs are required to practice corporate social responsibility, essentially from the principle of Tawhid. From an Islamic perspective, all possessions, wealth, expertise, abilities, position and power belong to Allah (swt). Mankind is only the trustee, and, hence, it is imperative that we manage these possessions to the best of our ability to create a maximum added value by the intention of creating benefit to the ummah (community) (Bardai, 2002).

\subsection{Islamic Corporate Social Reporting (ICSR) model}

According to Lewis (2001), the concept of social responsibility is related to the principle of full disclosure. It is argued that the concept of corporate social disclosure in the annual reports of IBOs requires a somewhat different set of requirements from the conventional Western format (Harahap, 2003). Social disclosure has a primary position in Islamic business culture, which emphasises the disclosure of truth (financial and non-financial information) and forbids the withholding thereof (Askary and Clarke, 1997). In Islam, the main objective of CSR is to show compliance with Islamic Shariah, i.e. to demonstrate accountability to Allah (swt) (Haniffa, 2002).

It is claimed that although the framework for the ICSR has a predominantly conventional flavour, social disclosure should comply with the Shariah Islamiyyah principles (Harahap, 2003; Haniffa, 2002; Baydoun and Willett, 1995), as well as being supported by the axiom of Tawhid. In addition, disclosure from an Islamic perspective of accounting means disclosing information that would aid economics as well as religious decision-making, and thus, should have the qualities of being relevant, objective and material (Haniffa et al., 2004).

Muhamad and Muwazir (2005) propose an ICSR based on the axiom of Tawhid, which focuses on the three main relationships (namely, man and Allah, man and other human beings, and man and the environment. They suggest that there are eleven aspects to be considered in disclosing corporate social responsibility information in the annual reports of IBOs. These aspects are briefly discussed as follows: 
1. Disclosure of corporate mission statement - the goals and objectives of IBOs are to operate in accordance with the ideals and principles of shariah (Haniffa and Hudaib, 2004).

2. Disclosure of information related to the top management - these are the key persons responsible to carry out the amanah entrusted to them. Detailed information on them would be beneficial for Muslim users of annual reports to assess their potential contribution towards the betterment of society (Muhamad and Muwazir, 2005; Abod, 2002).

3. Disclosure of unlawful (haram) operations - shariah prohibits business operations involving riba' (interest), gharar (uncertainty) and maisir (gambling), however, it encourages halal trade (Al-Qaradawi, 1995).

4. Disclosure of the Shariah Advisory Board (SAB) - the main role of the $\mathrm{SAB}$ is to provide assurance that the products and services produced by IBOs are in agreement with the will of Allah (swt) (Muhamad and Muwazir, 2005).

5. Disclosure on zakat obligation - detailed information regarding zakat obligation is crucial to Muslim users of financial statements as it is one of the five pillars of Islam (Muhamad and Muwazir, 2005; Haniffa, 2002; Hamid et al., 1993).

6. Employees' welfare - the concept of brotherhood entails that IBOs are responsible for the welfare and betterment of their employees, and that they should not treat employees unfairly (Muhamad and Muwazir, 2005; Alhabsyi, 1994).

7. Disclosure of products and services - transparency on products/services-related information is relevant and useful to users of annual reports to enable them to assess and judge the business conduct and its responsibility towards the society (Muhamad and Muwazir, 2005; Maali, Casson and Napier, 2003).

8. Disclosure of community involvement - IBOs are expected to contribute towards the betterment and well-being of the society in which they operate and generate money (Muhamad and Muwazir, 2005; Maali et al., 2003).

9. Disclosure of policy on insolvent client/debtors - the concept of brotherhood requires that Muslims be considerate (ihsan) to their fellow brothers in facing financial difficulty. Thus, Islam enjoins business organisations to be lenient with debtors facing difficulty in paying their debts (Muhamad and Muwazir, 2005; Maali et al., 2003; Haniffa, 2002). Disclosure of information relating to an IBO's policy towards its insolvent clients would be relevant and useful to help users of annual reports to judge its social responsibility.

10. Disclosure of Qard al-hasan funds - Qard al-hasan is an alternative to interest-bearing loans, which IBOs provide to individuals for socially beneficial purposes (Maali et al., 2003). Qard al-hasan is considered to be one of the social contributions of IBOs towards society. 
11. Environmental disclosure - disclosure relating to IBOs relationship with the environment is significant as it concerns how they look after Allah's creation on earth (Muhamad and Muwazir, 2005; Hassan, 2002)

\section{Previous studies}

This section briefly discusses previous studies on CSR. Ernst and Ernst (1978) categorise corporate social disclosure (CSD) into seven dimensions comprising the environment, energy, fair business practices, human resources, community involvement, products, and other aspects of social responsibility information. Various researchers have used these seven dimensions to investigate the extent of social reporting by organisations (for example: Gray, Javad, Power and Sinclair, 2001; Williams and Pei, 1999; Hackston and Milne, 1996; Clarke and Gibson-Sweet, 1999; Belkaoui and Karpik, 1989).

Table 1

CSR Studies in Developing Countries

\begin{tabular}{|c|c|c|}
\hline Studies & $\begin{array}{l}\text { Developing } \\
\text { Countries }\end{array}$ & Objective of the study and main Findings \\
\hline $\begin{array}{l}\text { Nik Ahmad and } \\
\text { Abdul Rahim, (2003) }\end{array}$ & Malaysia & $\begin{array}{l}\text { Investigates the awareness of managers about CSR } \\
\text { and found that although they are relatively aware, it } \\
\text { does not translate into high levels of reporting. }\end{array}$ \\
\hline $\begin{array}{l}\text { Kuasirikun and } \\
\text { Sherer, (2004) }\end{array}$ & Thailand & $\begin{array}{l}\text { Investigates the possibility of CSR disclosure in } \\
\text { Thailand and found that the Thai practices explored } \\
\text { fall short of their potential to function as enabling } \\
\text { communication. }\end{array}$ \\
\hline Bellal, (2001) & Bangladesh & $\begin{array}{l}\text { Measures the extent and volume of disclosure via } \\
\text { content analysis and found a low rate of disclosure. }\end{array}$ \\
\hline $\begin{array}{l}\text { Andrew, Gul, Guthrie } \\
\text { and Teoh (1989) }\end{array}$ & $\begin{array}{l}\text { Malaysia and } \\
\text { Singapore }\end{array}$ & $\begin{array}{l}\text { Examined } 119 \text { annual reports and found that only } 26 \\
\text { per cent had CSR disclosure. }\end{array}$ \\
\hline
\end{tabular}

In terms of the quantity of information disclosed by organisations relating to the disclosure theme the majority of social reporting studies showed consistent results, in which the item most disclosed in various countries is human resources (Bellal, 2001; Imam, 2000; Nafez and Kamal, 2000; Williams and Pei, 1999; Tsang, 1999; Gray, Owen and Maunders, 1988). According to Hackston and Milne (1996), disclosure on human resources was the most popular item disclosed by companies in New Zealand. Other items that were widely disclosed were community service, environmental and products (Gray et al., 2001; Williams and Pei, 1999; Hackston and Milne, 1996; Clarke and Gibson-Sweet, 1999; Belkaoui and Karpik, 1989).

Studies have shown that organisations in less developed countries have been quite slow in responding to the corporate social responsibility agenda. This situation is reflected somewhat, in the low levels of social and environmental reporting in company annual reports, as found in the studies listed in Table 1.

In the case of Malaysia, it was concluded that social responsibility disclosure is generally low, especially with regard to fair business information 
(Mohammad Jamil, Alwi and Mohamed, 2001). This also appears true for environmental information (ACCA, 2002). Evidence suggests that reporting by the Malaysian companies is still low (Nik Ahmad and Abdul Rahim, 2003). An analysis of the annual reports of 100 Malaysian public listed companies revealed that only 66 per cent of these companies made some form of CSD (Kin, 1990). Further analysis showed that in terms of theme, 64 companies disclosed information on product/service improvement/contribution, 31 companies on human resources, 22 companies on community involvement, and only 1 company on environmental disclosure.

\section{The Research Framework}

The framework for this study, as shown in Figure 3, indicates that the accounting system is influenced by culture. Particularly, this study focuses on religion (in this context the Islamic religion) as the main element of culture in shaping corporate social reporting (CSR). Specifically, the study investigates the main items of CSRI from the Islamic perspective that should be disclosed by IBOs, as perceived by Muslim accountants in Malaysia.

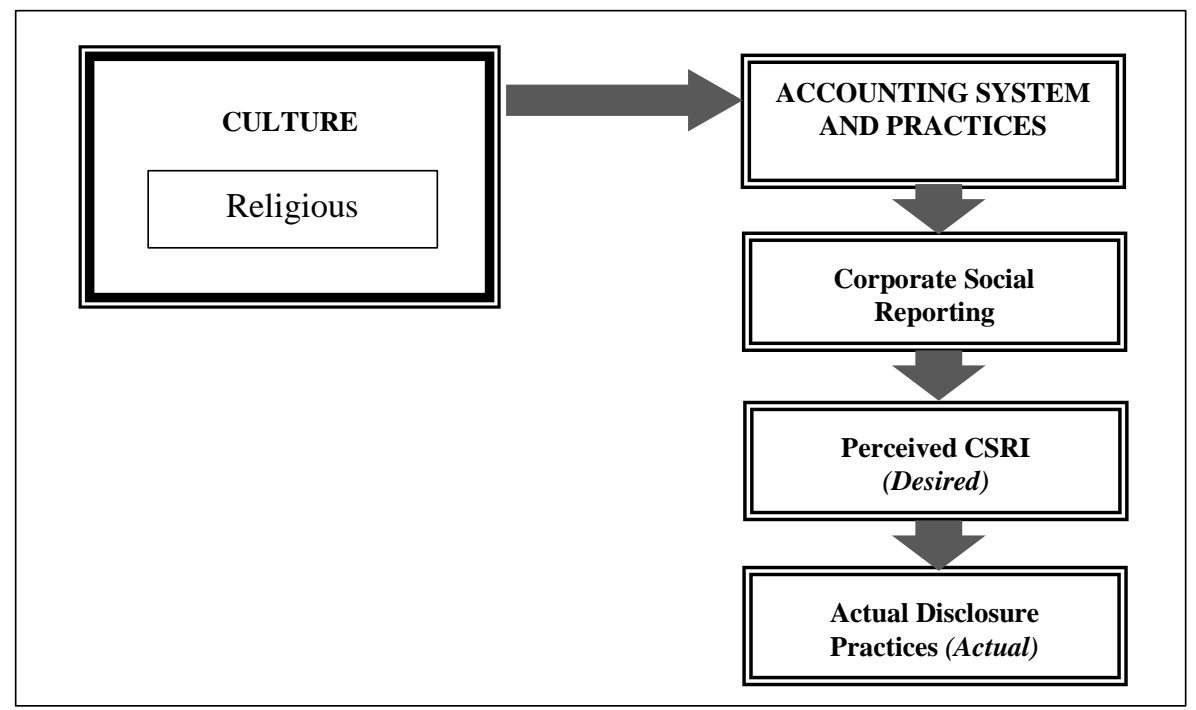

Figure 3: Research Framework

Content analysis and a questionnaire survey were used to gather data for this study. The annual reports of five (5) IBOs were analysed to examine the CSD practices. In total, 1500 questionnaires were sent out to Muslim accountants registered with the Malaysian Institute of Accountants (MIA) to determine the perceived ICSR. Out of the total questionnaires issued, 172 responses were received and all were found useable for this study. The questionnaire for this study is divided into three parts. Section A contains questions on respondents' opinion concerning various issues on corporate social 
reporting. Meanwhile, Section B solicits the perception of respondents about items of corporate social responsibility information to be disclosed in annual reports, while Section $\mathrm{C}$ captures the personal profile of the respondents. The questionnaire was developed based on previous studies conducted on CSR, both from the conventional (Gray et al., 1988; Teoh and Thong, 1984) and from the Islamic perspective (Muhamad and Muwazir, 2005; Haniffa and Hudaib, 2004; Maali et al., 2003; Haniffa, 2002).

Once gathered, the data were analysed using the Statistical Package for the Social Sciences (SPSS) version 11.5 program. An examination of the histogram output and the values of kurtosis and skewness indicate that all the items are reasonably normally distributed. Factor analysis was conducted to determine the validity of the ICSR items, while the Cronbach's alpha coefficient was used to ascertain its reliability.

\section{Findings}

This section provides discussion on the main findings from the study. Table 2 shows the demographic profiles of the respondents. The majority of the respondents are male and more than half are aged below 40 years. In terms of academic qualification, the majority have a first degree and have been working for more than 5 years. More than half of the respondents earn between RM2,000 and RM6,000.

Table 2

Demographic Profile

\begin{tabular}{llcc}
\hline Items & Categories & Frequency & $\%$ \\
\hline Gender & Male & 110 & 64.0 \\
Age & Female & 62 & 36.0 \\
& Below 30 years & 37 & 21.50 \\
& 31-40 years & 90 & 52.30 \\
& 41-50 years & 40 & 23.30 \\
& 51-60 years & 5 & 2.90 \\
\hline Level of academic & Diploma & 3 & 1.70 \\
qualification & Bachelor degree & 133 & 77.30 \\
& Master Degree & 34 & 19.80 \\
Working experience & Phd & 2 & 1.20 \\
& Below 5 years & 68 & 12.80 \\
& 6-10 years & 33 & 39.50 \\
& 11-15 years & 27 & 19.20 \\
& 16-20 years & 22 & 15.70 \\
Monthly income & Above 20 years & 6 & 12.80 \\
& Below rm2000 & 62 & 3.50 \\
& RM2001 to RM4000 & 45 & 36.00 \\
& RM4001 to RM6000 & 20 & 26.20 \\
& RM6001 to RM8000 & 18 & 11.60 \\
& RM8001 to RM10000 & 21 & 10.50 \\
& RM10001 and above & & 12.20 \\
\hline
\end{tabular}




\subsection{The main components of Islamic Corporate Social Responsibility}

Factor analysis was performed to extract the main components of Islamic corporate social responsibility, as perceived by Muslim accountants in Malaysia. The principal component analysis performed extracted five factors having eigenvalues greater than 1.0. The five factors accounted for $64.33 \%$ of the total variance. The orthogonal Varimax rotation approach was subsequently applied to the unrotated factors to obtain simpler and more meaningful factor solutions. Only those items with a factor loading of 0.3 and above on a single factor were retained in this study (Hair, Anderson, Tathan and Black, 1998). The component items of each factor were tested for internal consistency reliability using Cronbach's alpha coefficient. As reflected in Table 3, the alpha scores for the five factors are well above 0.6. It is argued that a coefficient of 0.6 or 0.5 is satisfactory (Nunnally, 1967).

Table 3

Islamic Corporate Social Information (ICSI)

\begin{tabular}{cc}
\hline Items & Factor \\
& Loading/ \\
& Mean \\
\hline
\end{tabular}

Islamic Business Policy and Operations $(\alpha=.95)$ :

1. The details on the balance of the zakat fund not yet distributed and the reason for $\quad .764 / 5.44$ the delay in distribution.

2. Disclosure of the amount of revenue (expenses) earned (paid) from unlawful operations.

$.744 / 5.34$

3. A statement showing the amount of zakat paid and its computation.

4. Explanation of the reasons for undertaking unlawful operations.

5. Statement of recommendations to rectify defects in products/services.

6. The attestation by the Shariah Advisory Board regarding the computation and distribution of the zakat funds.

7. Description regarding the basis of shariah concepts for each product/service.

8. The opinion of the Shariah Advisory Board regarding the necessity of

$.736 / 5.65$

$.699 / 5.63$

$.675 / 5.08$

$.669 / 5.52$

$.646 / 5.48$

$.594 / 5.45$ undertaking unlawful operations.

9. 9.A statement on the policy for appointing, re-appointment and dismissal of $\mathrm{BOD} /$ management team.

10. A statement describing the opinion of Shariah Advisory Board relating to penalty charges on late payments.

11. A statement describing details of products/services produced by the company and their side effects.

12. The details of the company's policy in dealing with insolvent clients.

13. A statement indicating that the company's policy on marketing is in compliance with Islamic ethical values.

14. A statement on the company's policy on late payments by clients.

$.579 / 5.22$

$.563 / 4.94$

$.507 / 5.27$

.5045 .02

$.493 / 5.27$

$.464 / 4.91$

$.424 / 5.32$

$.404 / 4.59$

16. A statement detailing the company's policy on equal opportunities towards women and minorities.

Contribution towards the Society and Conservation of the Environment $(\alpha=.91)$ :

1. A statement on contributions made to support acts by other organisations for the betterment of the society.

2. A description of company's participation in government social activities.

3. Description of company's contribution or activities undertaken to protect the $.650 / 5.15$ environment.

4. Description of the nature and amount spent on conservation of the natural environment and wildlife. 


\begin{tabular}{|c|c|c|}
\hline Item & & $\begin{array}{l}\text { Factor } \\
\text { Loading/ } \\
\text { Mean }\end{array}$ \\
\hline \multicolumn{3}{|c|}{ Contribution towards the Society and Conservation of the Environment $(\alpha=.91)$ : } \\
\hline & $\begin{array}{l}\text { Description of company's contribution towards the betterment of society, such as } \\
\text { programmes in helping to overcome social problems like poverty, illiteracy etc. }\end{array}$ & $.602 / 5.55$ \\
\hline & A statement describing employees training in relation to environmental issues. & $.587 / 4.81$ \\
\hline & $\begin{array}{l}\text { A statement indicating that the company's operations are in compliance with } \\
\text { environmental laws and regulation. }\end{array}$ & $.413 / 5.43$ \\
\hline & A statement indicating that the company's operations are non-polluting. & $.394 / 5.15$ \\
\hline & $\begin{array}{l}\text { Disclosure of any project that may have a negative impact on the natural } \\
\text { environment. }\end{array}$ & $.362 / 5.05$ \\
\hline \multicolumn{3}{|c|}{ Steps Taken to Ensure Shariah Compliance $(\alpha=.90)$ : } \\
\hline & $\begin{array}{l}\text { A statement stating that all products/services are approved by the Shariah } \\
\text { Advisory Board. }\end{array}$ & $.808 / 6.03$ \\
\hline & $\begin{array}{l}\text { Mission statement stating that the main objective of the company is to achieve } \\
\text { barakah (blessing) and al-falah (successful in the world and the hereafter) - } \\
\text { emphasising the importance of earning halal (permissible) profit. }\end{array}$ & $.756 / 5.89$ \\
\hline 3. & $\begin{array}{l}\text { A statement stating that the company's operations are based on shariah } \\
\text { principles. }\end{array}$ & $.731 / 5.76$ \\
\hline & $\begin{array}{l}\text { A description of the nature of unlawful operations, such as riba' (interest) and } \\
\text { gharar (ambiguity) activities. }\end{array}$ & $.696 / 5.84$ \\
\hline & A statement showing the sources and uses of zakat funds. & $.683 / 6.03$ \\
\hline & $\begin{array}{l}\text { A statement certifying that the distribution of profits and losses are made } \\
\text { according to shariah law. }\end{array}$ & $.538 / 5.71$ \\
\hline \multicolumn{3}{|c|}{ Information on Human Resources $(\alpha=.80)$ : } \\
\hline & $\begin{array}{l}\text { A statement on the remuneration of the management team and the Shariah } \\
\text { Advisory Board members. }\end{array}$ & $.744 / 5.34$ \\
\hline & $\begin{array}{l}\text { A statement disclosing information regarding employees' remuneration } \\
\text { (salaries/bonuses). }\end{array}$ & $.680 / 4.70$ \\
\hline & Details of names and profiles of BOD/management team. & $.647 / 5.85$ \\
\hline & $\begin{array}{l}\text { 4.Details regarding the qualifications of management team and Shariah Advisory } \\
\text { Board members. }\end{array}$ & $.510 / 5.84$ \\
\hline & Details regarding the members of the Shariah Advisory Board. & $.331 / 5.84$ \\
\hline \multicolumn{3}{|c|}{ Benefits and Welfare of Employees $(\alpha=.75)$ : } \\
\hline & $\begin{array}{l}\text { A statement detailing the company's policy on the working environment that is } \\
\text { conducive to Islamic ethical values. }\end{array}$ & $.661 / 5.43$ \\
\hline & $\begin{array}{l}\text { A statement detailing the company's policy on employees' welfare and benefits, } \\
\text { such as religious provision, holidays and medical benefits. }\end{array}$ & $.518 / 4.81$ \\
\hline & $\begin{array}{l}\text { A statement detailing the company's policy on the training/education } \\
\text { opportunities for employees. }\end{array}$ & $.475 / 4.99$ \\
\hline
\end{tabular}

Table 3 shows that five components of CSRI from an Islamic perspective have been extracted. Factor One consists of sixteen items, which are mainly related to Islamic business policy and operations. Factor Two comprises nine items with regards to the company's contribution towards the betterment of the society and conservation of the environment. Factor Three comprises six items that are generally related to steps taken by IBOs to ensure their operations are compliant with shariah law. The fourth factor mainly relates to information regarding the human resources in IBOs and the last factor consists of information on employees' welfare and benefits. These five factors reflect the five different categories of CSRI to be disclosed by IBOs, as perceived by Muslim accountants in Malaysia. The findings suggest that IBOs need to stress 
five different areas in the provision of CSRI in their annual reports. These are categorised as Islamic Business Policy and Operations; Contribution towards the Society and Conservation of Environment; Steps Taken to Ensure Shariah Compliance; Information on Human Resources, and Benefits and Welfare of Employees. The mean scores for all items of ICSI range from 4.59 and above, as reflected in Table 3, indicating that the respondents rated all items as being useful (we use a 7-point Likert scale for these questions).

It was observed that the mean scores of two out of the six items in Factor Three: Steps Taken to Ensure Shariah Compliance are more than 6.00, while the other four are approaching 6.00. The results indicate that Muslim accountants in Malaysia perceived that the items relating to the steps taken by IBOs to ensure shariah compliance as being very important to be disclosed in annual reports. Such a result reflects that the shariah compliance issue is crucial and needs to be fully addressed in the IBO operations.

As for Factor One: Islamic Business Policy and Operations, the mean scores of 13 out of 16 items are well above 5.00. Therefore, it can be inferred that information relating to Islamic business policy and operations is considered significant information to be disclosed in annual reports. Information pertaining to company's contribution to the betterment of the society and conservation of the environment ranges from 4.81 to 5.55 . It is reasonable to conclude that Muslim accountants also perceived this category of CSR information to be useful and that it should be disclosed to Muslim users of annual reports.

Details of information concerning the qualification and remuneration of the human resources is also perceived as important information to be disclosed, as the mean scores for all five items range from 4.70 to 5.85. The last factor, Factor Five: Benefits and Welfare of Employees, consists of three items and the mean scores for all these items range from 4.81 to 5.43 , implying that they are also considered significant elements of CSRI.

\subsection{Actual CSD Practices of Selected IBOs in Malaysia}

The researchers adopted the method used in the study by Hameed et al. (2005). In their study, they developed a total of 12 main themes, which were taken from the Malaysian Code of Corporate Governance and the Code of Best Practises for Corporate Governance in Islamic Financial Institutions (CGIFI). Table 4 shows the social reporting information by theme of five selected IBOs in Malaysia.

BIMB disclosed the most items in its annual reports (i.e. 42 items representing 66.7 per cent), as reflected in Table 4. Syarikat Takaful Malaysia was ranked second with 40 items being disclosed at 63.7 per cent. Takaful Nasional disclosed 30 items out of 63 , amounting to 47.7 per cent. This organisation did not disclose items pertaining to the appointment and reappointment of directors. It did however fully disclose information on 'Board Meetings', 'Remuneration Committee' and 'Basic Information' themes. 
BMB disclosed 29 items representing a percentage of 46.1 per cent. BMB did not disclose items for 'Appointment and Re-appointment', and 'Board Meetings' themes. It did however, disclose more items in 'Nomination Committee', 'Audit Committee', and 'SSB'. Etiqa Takaful has the least amount of disclosure compared to the other IBOs. It disclosed 22 items (or 35 per cent) in its annual reports. This organisation did not disclose items on 'Composition of Board of Directors', 'Appointment and Re-appointment', and 'SSB'.

Table 4

Social Reporting Information by Themes

\begin{tabular}{|c|c|c|c|c|c|c|c|c|c|c|c|}
\hline \multirow{3}{*}{ No. } & \multirow{3}{*}{ Themes } & \multicolumn{4}{|c|}{ Islamic Banking } & \multicolumn{6}{|c|}{ Takaful } \\
\hline & & \multicolumn{2}{|c|}{ BIMB $^{\mathrm{a}}$} & \multicolumn{2}{|c|}{$\mathrm{BMB}^{\mathrm{b}}$} & \multicolumn{2}{|c|}{$\begin{array}{c}\text { Takaful } \\
\text { Malaysia }\end{array}$} & \multicolumn{2}{|c|}{$\begin{array}{c}\text { Takaful } \\
\text { Nasional }\end{array}$} & \multicolumn{2}{|c|}{$\begin{array}{c}\text { Etiqa } \\
\text { Takaful }\end{array}$} \\
\hline & & $\mathrm{N}$ & $\%$ & $\mathrm{~N}$ & $\%$ & $\mathrm{~N}$ & $\%$ & $\mathrm{~N}$ & $\%$ & $\mathrm{~N}$ & $\%$ \\
\hline 1. & $\begin{array}{l}\text { Composition of } \\
\text { board of } \\
\text { directors }\end{array}$ & 1 & 1.6 & 1 & 1.6 & 1 & 1.6 & 1 & 1.6 & 0 & 0 \\
\hline 2. & $\begin{array}{l}\text { Appointment and } \\
\text { Re-appointment }\end{array}$ & 3 & 4.8 & 0 & 0 & 3 & 48 & 0 & 0 & 0 & 0 \\
\hline 3. & Board meetings & 3 & 4.8 & 0 & 0 & 3 & 4.8 & 3 & 4.8 & 3 & 4.8 \\
\hline 4. & $\begin{array}{l}\text { Directors' fees } \\
\text { and remuneration }\end{array}$ & 2 & 3.2 & 1 & 1.6 & 2 & 3.2 & 1 & 1.6 & 1 & 1.6 \\
\hline 5. & $\begin{array}{l}\text { Nomination } \\
\text { committee }\end{array}$ & 2 & 3.2 & 2 & 3.2 & 2 & 3.2 & 1 & 1.6 & 2 & 3.2 \\
\hline 6. & $\begin{array}{l}\text { Remuneration } \\
\text { Committee }\end{array}$ & 3 & 4.8 & 2 & 3.2 & 3 & 4.8 & 3 & 4.8 & 3 & 4.8 \\
\hline $\begin{array}{l}7 . \\
8 .\end{array}$ & $\begin{array}{l}\text { Audit Committee } \\
\text { Shariah }\end{array}$ & 7 & 11.1 & 7 & 11.1 & 7 & 11.1 & 5 & 7.9 & 1 & 1.6 \\
\hline & $\begin{array}{l}\text { Supervisory } \\
\text { Board (SSB) }\end{array}$ & 4 & 6.3 & 2 & 3.2 & 3 & 4.8 & 1 & 1.6 & 0 & 0 \\
\hline 9. & $\begin{array}{l}\text { Basic } \\
\text { Information }\end{array}$ & 2 & 3.2 & 2 & 3.2 & 2 & 3.2 & 2 & 3.2 & 2 & 3.2 \\
\hline 10. & $\begin{array}{l}\text { Financial } \\
\text { Statement }\end{array}$ & 5 & 7.9 & 5 & 7.9 & 5 & 7.9 & 5 & 7.9 & 5 & 7.9 \\
\hline 11. & $\begin{array}{l}\text { Social and } \\
\text { Environmental } \\
\text { Issues }\end{array}$ & 4 & 6.3 & 1 & 1.6 & 2 & 3.2 & 2 & 3.2 & 0 & 0 \\
\hline 12. & Others & 6 & 9.5 & 6 & 9.5 & 7 & 11.1 & 6 & 9.5 & 5 & 7.9 \\
\hline & Total & 42 & 67 & 29 & 46 & 40 & 64 & 30 & 48 & 22 & 35 \\
\hline
\end{tabular}

\section{Conclusion}

The analysis of the desired, as observed from the perception of Muslim accountants representing preparers of annual reports, showed that five categories of CSRI are perceived as useful and thus should be disclosed in the annual reports of IBOs. These five components comprised Islamic Business Policy and Operations; Contribution towards the Society and Conservation of Environment; Steps Taken to ensure Shariah Compliance; Information on Human Resources, and Benefits and Welfare of Employees. Thus, supporting 
the idea that that there are circumstances under which culture and religion may affect societal values, such as the accounting system and practices (Hofstede, 1988). Generally, the items contained in these five factors cover the eleven aspects described in the ICSR model suggested by Muhamad and Muwazir (2005).

The analysis of the actual, as found in the result of the content analysis conducted on the annual reports of five selected IBOs, revealed that most of IBOs disclose on CSRI and that the difference among the organisations lies in the focus of the items being disclosed. The findings also indicated that BIMB, being the oldest and the largest Islamic bank in Malaysia, disclosed the most information. There are two factors; namely, Islamic Business Policy and Operations, and Steps Taken to ensure Shariah Compliance that are not being emphasised in the annual reports of these IBOs. Thus, we conclude that there is a gap between the actual and the desirable as well as between the actual and the desired.

Future studies may embark on a comparative study among Muslim countries globally so that more knowledge could be gained from the experiences and unique conditions of these individual countries.

\section{References}

Abdalati, H. (1998). Islam in Focus and Commentary, 3rd edition, USA: American Trust.

Abdullah, K. (1999). National Security and Malay Unity: The Issue of Radical Religious Elements in Malaysia. Contemporary Southeast Asia, 2(2): 261272.

Abod, S.G. (2002). Towards an Islamic Corporate Governance, Corporate Governance from the Islamic Perspective. Nik Mustapha Nik Hassan and Shaikh Mohd Saifuddeen Shaikh Mohd Salleh (eds.) Kuala Lumpur: Institute of Islamic Understanding Malaysia (IKIM): 93-110.

ACCA (Association of Chartered Certified Accountants) (2002). The State of Corporate Environmental Reporting in Malaysia, www.accaglobal.com

Ahmad, K. (1977). Islam: Its Meaning and Message. New Delhi: Ambika Publications.

Al-Attas, S.M.N. (1985), Islam, Secularism, and The Philosophy of the Future, London, Mansell.

Alhabshi, S.O. (1994). Corporate Ethics in the Management of Corporations. The Malaysian Accountant: 22-24.

Al-Qaradawi, Y. (1995). Dawr Al-Qiyam Wal-Akhlaaq Fi Al-Iqtisaad AlIslaami, Maktabat Wahbah.

Andrew, B.H., F.A. Gul, J.E. Guthrie and H.Y. Teoh (1989). A Note on Corporate Social Disclosure Practices in Developing Countries: A Case of Malaysia and Singapore, British Accounting Review, 21: 371-76. 
Archambault, J.J. and Archambault, M.E. (2003). A Multinational Test of Determinants of Corporate Disclosure. The International Journal of Accounting, 38(2): 173-194.

Askary, S. and Clarke, F.L. (1997). Accounting in Islam. Accounting, Commerce \& Finance: The Islamic Perspective, 1(1): 139-152.

Bakadar, A. A. (1997). Islamic Principles for the Conservation of the Natural Environment. Islam and the Environment. A. R. Agwan (ed.) Kuala Lumpur: Synergy Book International: 71-108.

Bardai, B. (2002). Ethical Responsibility and the Role of CEOs and Board of Director in Business Corporations - An Islamic Perspectives. Corporate Governance from the Islamic Perspective. Nik Mustapha Nik Hassan and Shaikh Mohd Saifuddeen Shaikh Mohd Selleh (eds.). Kuala Lumpur: Institute of Islamic Understanding Malaysia (IKIM): 25-42.

Baydoun, N, and Willett, R (1995). Cultural Relevance of Western Accounting Systems to Developing Countries. ABACUS, 31(1):67-92.

Baydoun, N. and Willet, R. (1997). Islam and Accounting: Ethical in the Presentation of Financial Information. Accounting, Commerce and Finance: The Islamic Perspective, 1(1): 15-19.

Baydoun, N. and Willet, R. (2000). Islamic Corporate Report. ABACUS, 36(1): 71-90.

Belkaoui, A. and Karpik, P.G. (1989). Determinants of The Corporate Decision to Disclose Social Information. Accounting, Auditing and Accountability Journal, 2(1): 36-51.

Bellal, A.R. (2001). A Study of Corporate Social Disclosure in Bangladesh. Managerial Auditing Journal, 16(5): 274-289.

BIMB, (1994). Islamic Banking and Practice from the Practioner's Perspective, Kuala Lumpur: BIMB.

Clarke, J. and Gibson-Sweet, M. (1999). The Use of Corporate Social Disclosures in The Management of Reputation and Legitimacy: A Cross Sectoral Analysis of UK Top 100 Companies. Business Ethics: A European Review, 8(1): 5-13.

Dusuki, A.W. (2008). What Does Islam Say About Corporate Social Responsibility? Review of Islamic Economics, 12(1): 5-28.

Ernst and Ernst (1978). Social Responsibility Disclosure: 1978 Survey. Ernst and Ernst, Cleveland, $\mathrm{OH}$.

Frederick, W.C. (1994). From CSR1 to CSR2. Business and Society, 33(2): 150-164.

Gray, R., Javad, M., Power, M.D. and Sinclair, C.D. (2001). Social and Environmental Disclosure and Corporate Characteristics: A Research Note and Extension. Journal of Business Finance and Accounting, 28(3/4): 327356.

Gray, R., Owen, D. and Maunders, K. (1988). Corporate Social Reporting: Emerging Trends in Accountability and The Social Contact. Accounting, Auditing \& Accountability Journal, 1(1): 6-20. 
Gray, R.H., Kouhy, R. and Lavers, S. (1995). Corporate social and environmental reporting: a review of literature and a longitudinal study of UK disclosure. Accounting Auditing \& Accountability Journal, 8(2): 47-77. Gray, S.J. (1988). Towards a Theory of Cultural Influence on the Development of Accounting System Internationally. ABACUS, 24(1): 1-15.

Gray, S.J., Owen D. and Adams C. (1996). Accounting and Accountability: Changes and Challenges in Corporate Social and Environmental Reporting, UK: Prentice-Hall.

Hackston, D. and Milne, M.J. (1996). Some Determinants of Social Environmental Disclosures in New Zealand Companies. Accounting, Auditing and Accountability Journal, 9(1): 77-108.

Hair, J.F., Anderson, R.E., Tathan, R.L. and Black, W.C. (1998). Multivariate Data Analysis, $5^{\text {th }}$ Edition, New Jersey: Prentice Hall.

Hamid S., Craig, R., and Clarke F. (1993). Religion: A Confounding Cultural Element in the International Harmonisation of Accounting, ABACUS, 29(2): 131-148.

Haniffa, R. and Hudaib, M. (2004). Disclosure Practices of Islamic Financial Institutions: An Exploratory Study. (in Accounting, Commerce and Finance: The Islamic Perspective International Conference V, Brisbane, Australian: 15-17.

Haniffa, R. (2002). Social Responsibility Disclosure: An Islamic Perspective. Indonesian Accounting and Management Journal, 1(2): 128-146.

Haniffa, R. Hudaib, M. and Mirza, A.M. (2004). Accounting Policy Choice Within the Shari'ah Islami'ah Framework. Discussion Paper 02/04, University of Exeter, Available from: www.ex.uk/sobe/Research/DiscussionPaperAccFin2002/

Harahap, S.S. (2003). The Disclosure of Islamic Value in Annual Reports - the Analysis of Bank Muamalat Indonesia's Annual reports. Managerial Finance, 29(7): 70-89.

Hassan, N.M.N. (2002). Business Social Responsibility from the Islamic Perspective. Corporate Governance from the Islamic Perspective. Hassan, N.H.N. and Shaikh Mohd Saifuddeen Shaikh Mohd Salleh (eds.). Kuala Lumpur: Institute of Islamic Understanding Malaysia (IKIM): 25-42.

Herbig, P., and Dunphy, S. (1998). Culture and innovation. Journal of Management Development, 5(4): 13-21.

Hillerbrand, C. and Money, K. (2007). Corporate Responsibility and Corporate Reputation: Two Separate Concepts or Two Sides of the Same Coin? Corporate Reputation Review, 10(4): 261-277.

Hofstede, G. (1988). Culture's Consequences - International Differences in Work-Related Values, Sage, Beverly Hills, CA.

Hopwood, A.G. (1983). In Trying to Understand Accounting in The Contexts in Which It Operates. Accounting, Organizations and Society, 8(2/3): 287305 . 
Hunt, S.D. and Vitell, S. (1986). A General Theory of Marketing Ethics. Journal of Macromarketing, 8:5-16.

Imam, S. (2000). Corporate Social Performance Reporting in Bangladesh. Managerial Auditing Journal, 15(3): 133-41.

Innes, J. and Norris, G. (2005). Corporate Social Responsibility: A case study guide for Management Accountants, CIMA Publishing.

Jaggi, B.L. (1975). The Impact of Cultural Environment on Financial Disclosure The International Journal of Accounting Education and Research, 10(2): 75-84.

Karake, Z.A. (1998). An Examination of the Impact of Organisational Downsizing and Discrimination Activities on Corporate Social Responsibility as Measured by a Company's Reputation Index. Management Decision, 36(3): 206-16.

Kin, H.S. (1990). Corporate Social Responsibility Disclosures in Malaysia. Akauntan Nasional: 4-9.

Kuasirikun, N., and Sherer, M. (2004). Corporate social accounting disclosure in Thailand. Accounting, Auditing and Accountability Journal, 17(4): 629660.

Lewis, M.K. (2001). Islam and Accounting. Accounting Forum, 25(2): 103-127.

Maali, B., Casson, P. and Napier, C. (2003). Social Reporting by Islamic Banks. Discussion Papers in Accounting and Finance, Number AF03-13, University of Southampton.

Mohammad Jamil, C.Z., K. Alwi and R. Mohamed (2001). Corporate Social Reporting Disclosure in the Annual Reports of the Malaysian Companies: A Longitudinal Study. (WP-10/2001; Kedah Malaysia: Universiti Utara Malaysia).

Mohammed, D.A. (2013). An Islamic Perspective of Corporate Social Responsibility. Retrieved from www.worldresearchconference.com: http://www.worldresearchconference.com/

Muhamad, R. and Muwazir, M. R. (2005). Corporate Social Responsibility and Islamic Business Organizations: A Proposed Model (in the International Conference of Global Business in Services: Challenges, Uncertainty and Opportunities, Bali, Indonesia, 27-29 July 2005).

Nafez, A.B. and Kamal, N. (2000). Empirical Evidence On Corporate Social Disclosure (CSD) Practices in Jordan. International Journal of Commerce \& Management, 10(3/4): 18-34.

Naqvi, S.N.H. (1981). Ethics and Economics: An Islamic Synthesis, UK: The Islamic Foundation.

Nik Ahmad, N.N. and Abdul Rahim, N.L.A (2003). Awareness of the concept of Corporate Social Responsibility (CSR) among Malaysian managers in selected public listed companies. Paper presented at the 7 the International Conference on Global Business and Economic Development, Bangkok, Thailand, 8-11 January 2003. 
Nor, S. M., and Hashim, N. A. (2014). CSR and Sustainability Dimension in Islamic Banking in Malaysia: A Management Insight. Proceedings of 26th International Business Research Conference 7 - 8 April 2014, Imperial College, London, UK, ISBN: 978-1-922069-46-7

Nunnally, J.C.Jr. (1967). Psychometric Theory. New York: McGraw-Hill.

Palau, S.L. (2001). Ethical Evaluations, Intentions and Orientations of Accountants: Evidence from a Cross-Cultural Examination. International Advances in Economic Research, 7(3): 351-364.

Perera, M.H.B. (1989). Towards a Framework to Analyze the Impact of Culture on Accounting. International Journal of Accounting, 24: 42-56.

Sadler, W. (1970). Personality and Religion: The Role of Religion in Personality Development, London: SCM Press Ltd.

Selvaraj, S.D. and Muhamad, R. (2004). Islamic Accounting Framework. Accounting Theory and Practice: A Malaysian Perspective. S. Susela Devi, Keith Hooper and Howard Davey (eds.). Kuala Lumpur: Prentice Hall.

Teoh, H.Y., and G. Thong (1984). Another Look at Corporate Social Responsibility and Reporting: An Empirical Study in A Developing Country. Accounting, Organisations and Society, 9(2): 189-206.

Tsang, E.W.K. (1999). A Preliminary Typology of Learning in International Strategic Alliances. Journal of World Business, 34: 211-29.

Violet, W. J. (1983). The Development of International Accounting Standards: An Anthropological Perspective. The International Journal of Accounting, Spring: 1-12.

Williams, G. and Zinkin, J. (2010). Islam and CSR: A study of the compatibility between the tenets of Islam and the UN Global Compact. Journal of Business Ethics, 91(4): 519-533.

Williams, S.M. and Pei, C-A.H.Wern (1999). Corporate social disclosures by listed companies on their web sites: an international comparison. The International Journal of Accounting, 34(3): 389-419.

Yusoff, N.M.A.N. (2002). Islam and Business, Kelana Jaya: Pelanduk Publications.

Zadek, S., Pruzan, P. and Evans, R. (1997). Building Corporate Accountability: Emerging Practices in Social and Ethical Accounting, Auditing and Reporting, Earthscan Publications: London.

Zaidan, A.K. (1999). al-Madkhal li Dirasah al-Shari'ah al-Islamiyyah. Beirut: Al-Resalah Publishers. 